\title{
Diel vertical migration and the haemocyanin of krill Meganyctiphanes norvegica
}

\author{
John I. Spicer ${ }^{1, *}$, Jarl-Ove Strömberg ${ }^{2}$ \\ ${ }^{1}$ School of Biological Sciences, University of Plymouth, Plymouth PL4 8AA, United Kingdom \\ ${ }^{2}$ Royal Swedish Academy, Kristineberg Marine Research Station, Kristineberg 2130, Fiskebäckskil 450 34, Sweden
}

\begin{abstract}
Changes in environmental factors $\left(\mathrm{PO}_{2}\right.$, temperature, salinity and food availability) influence the concentration of the respiratory pigment haemocyanin ([Hc]) present in many crustaceans. We investigated the possibility that [Hc] and $\mathrm{HcO}_{2}$ affinity altered during the diel vertical migration (DVM) of Nordic krill Meganyctiphanes norvegica in the Gullmarsfjord, Sweden. The [Hc] decreased with increasing depth, for individuals both trawled and caged at different depths. Laboratory experiments indicated that this pattern could not be explained by differences in $\mathrm{PO}_{2}$, temperature or salinity. Alternatively, starvation had a significant effect on [Hc] over the course of a few $h$ $(\leq 10)$, i.e. a much shorter time scale than found for other crustacean species. Starved individuals showed a dramatic decrease in [Hc] compared with fed individuals. This decrease was exacerbated by an increase in temperature. We suggest that when $M$. norvegica migrates into deep water during the day, for whatever reason (predator avoidance or reduced prey abundance, or reduced ability to locate and capture prey), they cannot secure enough energy to meet routine metabolic demands; they therefore break down Hc and use it as an energy source. We conclude that there is likely to be a trade-off between the respiratory function of Hc and its importance in nutrition when krill migrate into deeper, nutritionally poorer waters during their DVM.
\end{abstract}

KEY WORDS: Feeding · Hypoxia · Salinity · Temperature · Starvation · Respiratory pigment · Ecophysiology Resale or republication not permitted without written consent of the publisher

\section{INTRODUCTION}

Alterations in the structure, function and concentration of crustacean haemocyanins (Hc) as a result of changes in environmental variables are relatively well documented (Mangum 1983, 1990, 1997, Truchot 1992, Bridges 2001). Pre-exposure to hypoxia increased both Hc concentration ([Hc]) and $\mathrm{HcO}_{2}$ affinity (Senkbeil \& Wriston 1981, Hagerman \& Oksama 1985, Hagerman \& Uglow 1985, Hagerman 1986, DeFur et al. 1990, Spicer \& Baden 2001), with changes in the latter often associated with altered molecular subunit configuration (Mangum 1994), at least in the laboratory. In situ, however, more chronic and severe hypoxic exposure often resulted in a precipitous decrease in [Hc] (Baden

*E-mail: jispicer@plymouth.ac.uk et al. 1990). Similarly, laboratory exposure to hyposaline conditions was often accompanied by increases in both [Hc] and $\mathrm{HcO}_{2}$ affinity as well as changes in $\mathrm{Hc}$ structure (Boone \& Schoffeniels 1979, Mason et al. 1983). Temperature also effected changes in Hc function, although this has received less (experimental) attention than either hypoxia or salinity (Rutledge 1981, Mangum 1997). In addition, the effect of food availability on [Hc] has been investigated (Uglow 1969, Djangmah 1970, Dall 1974, Hagerman 1983). Mostly the changes elicited by temperature, hypoxia and food availability have been studied over a timescale of many days and in some cases weeks and months.

Most krill species undergo a diel vertical migration (DVM) (Mauchline \& Fisher 1969, Mauchline 1980). Nordic krill Meganyctiphanes norvegica (M. Sars) undergoes a pronounced DVM throughout its geographical range (Sameoto 1980, Simmard et al. 1986, 
Buchholz et al. 1995, Onsrud \& Kaartvedt 1998, Tarling et al. 1998, Liljebladh \& Thomasson 2001), a behaviour widely thought to result from a trade-off between securing food (surface layers) and reducing predation (deeper layers) (Banse 1964, Lampert 1989, Tarling et al. 2000, Alonzo \& Mangel 2001). This may necessitate traversing pycnoclines resulting in individuals periodically residing in bodies of water that may differ dramatically in their temperature, salinity and $\mathrm{O}_{2}$ properties (Mauchline \& Fisher 1969, Simmard et al. 1986, Onsrud \& Kaardvedt 1998, Spicer et al. 1999). The DVM of $M$. norvegica inhabiting a Swedish fjord, at certain times of the year (e.g. after the annual exchange between bottom water in the fjord and the Skaggerak had failed), took them into deep hypoxic waters which severely tested their aerobic/anaerobic capacity (Spicer et al. 1999, Strömberg \& Spicer 2000). Water bodies on either side of such a pycnocline could also vary in food availability.

Since there can be dramatic and rapid differences in the environmental conditions experienced by krill traversing pycnoclines, it is pertinent to investigate whether such changes have any effect on krill ecophysiology. Consequently, here we investigated [Hc] and $\mathrm{HcO}_{2}$ affinity during DVM by Meganyctiphanes norvegica. To do this, krill were collected from different depths both during the day and night in the course of a natural DVM in the Gullmarsfjord, Sweden, and their Hc examined. The natural DVM was also 'manipulated' by caging krill at different depths in situ. Furthermore, we examined the effects of $\mathrm{O}_{2}$ tension $\left(\mathrm{PO}_{2}\right)$, temperature, salinity and food availability on krill [Hc] and $\mathrm{HcO}_{2}$ affinity in the laboratory. This was done both over timescales appropriate to the natural DVM (h) and over longer periods (d) in order to (1) check that we were not missing physiological changes because of using such a short time scale; and (2) provide comparative data. We hypothesised that krill [Hc] and $\mathrm{HcO}_{2}$ affinity would not change in response to any of the alterations in environmental factors over the timecourse of natural DVM (null hypothesis) but might change in the longer term. We used laboratory-based studies to interpret physiological changes that we observed in situ, as rarely has the field relevance of such laboratory studies been examined experimentally (but see Baden et al. 1990, Mangum 1994, Spicer \& Baden 2000, 2001 for exceptions).

\section{MATERIALS AND METHODS}

Krill capture and maintenance. The krill Meganyctiphanes norvegica were collected from the Gullmarsfjord, SW Sweden $\left(58^{\circ} 19.9^{\prime} \mathrm{N}, 11^{\circ} 33.8^{\prime} \mathrm{E}\right)$ between 27 July and 20 August 1999). Swarms were located using an echo sounder $(120 \mathrm{kHz}$ Lowrance X-15M, transducer 8 degree) and collected using an IsaacsKidd Midwater Trawl (mouth size $=0.6 \mathrm{~m}^{2}$, haul duration $=10 \mathrm{~min}$, depth $=85$ to $105 \mathrm{~m}$ ). Harvested individuals were then either: (1) placed in cages and redeployed at different depths for a specified period of time (Manipulation of DVM experiment); or (2) taken to the laboratory at Kristineberg Marine Research Station within $<90 \mathrm{~min}$ of capture. Here, they were used in experiments to determine the effect of salinity, hypoxia and starvation on $[\mathrm{Hc}]$. Only data from large (>43 mm body length, >0.495 g wet mass) intermoult adults were used in analyses. The only exception was krill collected on 19 July 2001, where as many moult stages as possible were used in an experiment investigating how $[\mathrm{Hc}]$ changed with moult stage. Moult stages were determined using Buchholz (1982).

Values for temperature, salinity, $\mathrm{PO}_{2}$ and chlorophyll content were obtained on 4 July, 3 August and 4 September 1999, from the same collection site by the RV 'Arne Tiselius' as part of the Kristineberg Pelagic Monitoring Scheme.

Krill were maintained in the laboratory in opaque fibre-glass aquaria (vol $=350 \mathrm{l}$, stocking density $<0.5$ ind. $\mathrm{l}^{-1}$. These aquaria were covered to keep the krill in darkness and supplied with natural sea water, pumped into the station (intake depth $\approx 40 \mathrm{~m}, \mathrm{~T}=7^{\circ} \mathrm{C}$, $\mathrm{S}=31 \mathrm{PSU}, \mathrm{PO}_{2}=17.9 \mathrm{kPa}$ ). Individuals were introduced into experiments $<2 \mathrm{~d}$ after capture.

Field studies. Natural DVM: To investigate potential in situ differences in $[\mathrm{Hc}]$ related to depth and time of day, krill were collected from 3 different depths (day and night) using the method described above. Haemolymph samples were obtained from a large number of freshly collected individuals (10 to $44 \mathrm{~min}$ after capture) on the following occasions during 1999: 09:05 to 11:15 h on 10 August sampling at 3 different depths, 10 to 20,20 to 30 and 95 to $105 \mathrm{~m}_{i} 01: 10$ to 03:00 h on 12 August sampling at 3 different depths, 10 to 20,20 to 30 and 95 to $110 \mathrm{~m}$. Unfortunately, due to logistic difficulties, it was not possible to collect krill between depths of 30 and $95 \mathrm{~m}$. Haemolymph was extracted and kept on ice until the $[\mathrm{Hc}]$ and $\mathrm{HcO}_{2}$ binding could be examined as described below.

Manipulation of DVM: To investigate the effect on $[\mathrm{Hc}]$ of maintaining krill at different depths in the water column by using cages to prevent them from undertaking DVM, the following experiment was carried out from 10 to 11 August 1999. Krill were collected from a depth of 90 to $100 \mathrm{~m}$ at the Gullmarsfjord site during the morning of 10 August. Individuals from 3 catches were pooled, and those in intermoult transferred haphazardly to each of 8 cages ( $\mathrm{vol} \approx 30 \mathrm{l}$, mesh size $=1 \mathrm{~mm}$ ). Each cage, containing ca. 30 individuals, was lowered $(<2 \mathrm{~h}$ after krill collection) to 1 of 9 dif- 
ferent water depths $(38,42,48,60,67,72,95,100$ and $105 \mathrm{~m})$ which roughly encompassed the range traversed by krill during DVM. The stocking density of the krill was based on conservative estimates of 1 ind. $\mathrm{l}^{-1}$ for populations in the Clyde Sea area (Mauchline \& Fisher 1969) as there are no equivalent data for the Gullmarsfjord. The cages were retrieved $16 \mathrm{~h}$ after deployment. Upon retrieval, mortality was noted and haemolymph sampled from surviving individuals as described below. All individual samples were kept on ice $(<2.5 \mathrm{~h})$ awaiting analysis.

In a further, but less extensive, experiment, $60 \mathrm{krill}$ collected from a depth of 95 to $110 \mathrm{~m}$ depth during the early hours of 12 August, were caged at a depth of 5 to $10 \mathrm{~m}$. Krill rarely migrate into these surface layers and so it was important to determine if this was because they could not survive environmental conditions there due to warmer and less saline conditions than found in deeper waters, or indeed if they could, and subsequently as to what effect this would have on the [Hc]. Cages were retrieved 0.5, 1 and $2 \mathrm{~h}$ after deployment.

Effect of environmental $\mathrm{PO}_{2}$ and salinity on [Hc] and $\mathrm{HcO}_{2}$ binding. To investigate the effect of environmental hypoxia on the [Hc] and $\mathrm{HcO}_{2}$ binding, the following experiment was carried out. The number of individuals used was determined by availability of intermoults in our collections. Sixty individuals were introduced into each of 4 aquaria (vol $=28 \mathrm{l}, \mathrm{T}=7^{\circ} \mathrm{C}$, $\mathrm{S}=31 \mathrm{PSU}$ ). This gave a density of ca. 2 ind. $\mathrm{l}^{-1}$. The water in 2 of the aquaria was maintained throughout the experiment at $\mathrm{PO}_{2}=8.1 \mathrm{kPa}$ (hypoxic treatment) by equilibrating it with an air-nitrogen mixture produced by precision gas mixing pumps (Wöstoff). Water in the remaining 2 aquaria was gently aerated $\left(\mathrm{PO}_{2} \mathrm{ca}\right.$. $20 \mathrm{kPa}$ ) (normoxic control treatment). Thirteen individuals were removed from each tank after 5, 10 (ca. the duration of the krill's stay in the deeper hypoxic water), 24 and $51 \mathrm{~h}$ after initial exposure to hypoxia. Haemolymph was sampled $<20 \mathrm{~s}$ after the removal of the individual from the aquarium, as described below, and kept on ice until analysis. The remaining individuals were removed after $51 \mathrm{~h}$ and their haemolymph extracted and pooled in $2 \times 100 \mu \mathrm{l}$ aliquots per treatment for subsequent construction of $\mathrm{HcO}_{2}$-binding curves. This experiment was carried out twice.

To investigate the effect on $[\mathrm{Hc}]$ and $\mathrm{HcO}_{2}$ binding of transferring krill to different salinities, the following experiment was carried out. Twenty-six large adult individuals were introduced into each of 10 aquaria $(\mathrm{vol}=18 \mathrm{l})$, with each duplicate containing 1 of 5 different seawater dilutions $(\mathrm{S}=35,28,21,14$ and $7 \mathrm{PSU}$, $\mathrm{T}=7^{\circ} \mathrm{C}$ ). This gave a density of ca. 1.5 ind. $\mathrm{l}^{-1}$. Five, 10 , 24 and $50 \mathrm{~h}$ after the initial exposure to low salinity, 6 to 8 live individuals were removed from each tank. Again, haemolymph was extracted $<20$ s after re- moval of the individual and kept on ice before analysis. The remaining individuals were removed and their haemolymph extracted and pooled $(2 \times 100 \mu \mathrm{l}$ aliquots per salinity treatment) for subsequent construction of $\mathrm{HcO}_{2}$-binding curves. This experiment was carried out twice.

In both sets of experiments, krill were supplied with food. The water in each aquarium was spiked with known amounts of the diatom Thalasseosira weissflogii (supplied by Dr. M. St John) so that the final [C] $=0.3 \mathrm{mg} \mathrm{l}^{-1}$. The desired concentration was maintained by replenishing the water with diatom culture after every $5 \mathrm{~h}$ period. This corresponded to food availability during a spring bloom in the Gullmarsfjord (M. St John pers. comm.).

Effects of environmental temperature and starvation on [Hc]. To examine the effect of temperature and starvation on krill [Hc] over a timescale relevant to DVM, the following experiment was carried out. Sixteen aquaria were set up, each filled with filtered (mesh size $=0.2 \mu \mathrm{m})$ natural seawater $(\mathrm{vol}=15 \mathrm{l}, \mathrm{S}=34$ PSU). Eight were maintained at a temperature of $7^{\circ} \mathrm{C}$ and the other 8 at $14^{\circ} \mathrm{C}$. These temperatures were chosen as they were close to the extremes encountered by krill in the fjord at this time of year (July-August). The water in 4 aquaria held at each of the experimental temperatures (i.e. 8 in total) was spiked with the diatom Thalassiosira weissflogii to give a final nominal $[C]=0.3 \mathrm{mg} \mathrm{l}^{-1}$. Krill in the remaining aquaria were not provided with any food. Twenty individuals were then introduced into each aquaria. Krill density was ca. 1.3 ind. $\mathrm{l}^{-1}$. Krill were removed individually after $10 \mathrm{~h}$ exposure and their haemolymph sampled.

Effect of moult stage on [Hc]. The effect of moult stage on krill [Hc] was determined as follows. Individuals were collected (95 $\mathrm{m}$ depth), returned to the laboratory within $<3 \mathrm{~h}$ of capture and were maintained there for $24 \mathrm{~h}$, all exactly as described above. After this time, individuals at different stages of the moult cycle were removed and their haemolymph sampled.

Haemolymph sampling and analysis. Immediately upon removal from the water, individual krill were quickly and gently blotted dry using tissue paper. Particular attention was given to the area under the carapace where the abdomen joins the thorax, as water was often retained there due to surface tension effects. Haemolymph (10 to $25 \mu \mathrm{l}$ ) was extracted from individuals using a microsyringe (Hamilton, $50 \mu \mathrm{l}$ capacity), the needle of which was inserted dorsally, directly into the pericardium, via the arthrodial membrane that joins the abdomen to the thorax. If $<10 \mu$ l was obtained from an individual krill, then the haemolymph was not kept as an individual sample but was instead pooled, in order to obtain enough haemolymph for the construction of $\mathrm{HcO}_{2}$-binding curves. Haemolymph was 

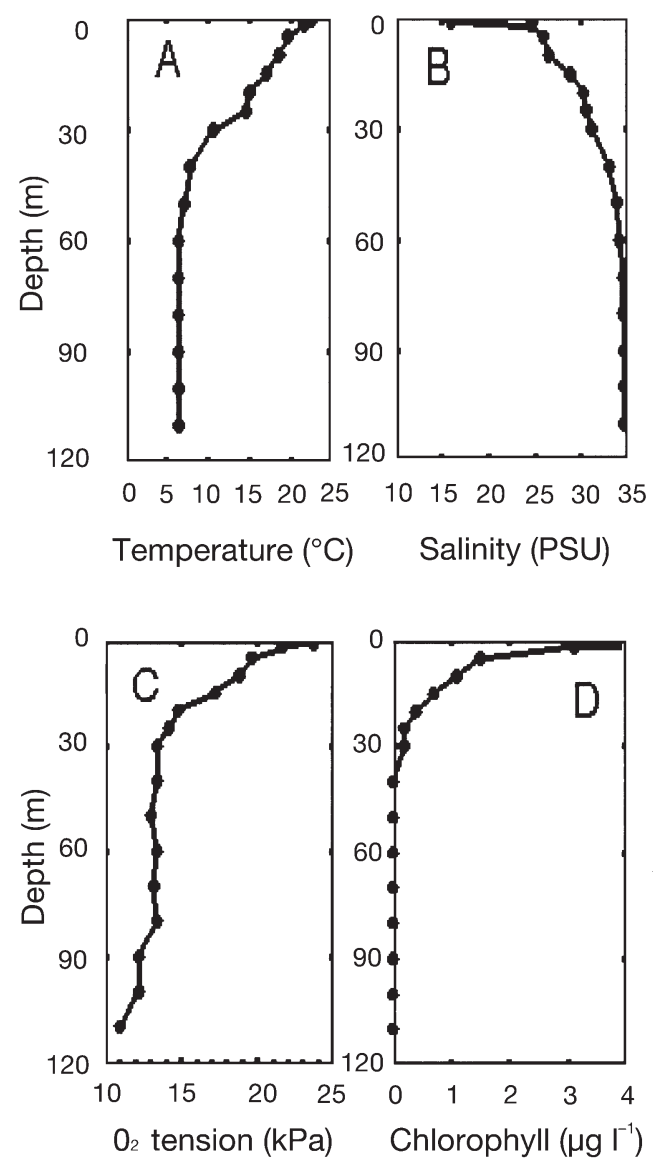

Fig. 1. Temperature, salinity, oxygen and chlorophyll profiles for the study site in Gullmarsfjord during the course of this study, measured on 3 August 1999

carefully transferred to a microcentrifuge tube (Eppendorf, vol $=1.6 \mathrm{ml}$ ) and kept on ice while awaiting analysis.

The [Hc] in the haemolymph of individual krill was estimated using an established spectrophotometric method (Nickerson \& van Holde 1971, Hagerman 1983, Baden et al. 1990). Twenty $\mu \mathrm{l}$ of haemolymph were made up to a final volume of $600 \mu \mathrm{l}$ with an appropriate saline solution (Schlieper 1972, p 335). The absorbance of the resultant mixture $(\lambda=335 \mathrm{~nm})$ was measured using a spectrophotometer (Hitachi U2000). Matched quartz cuvettes (Hel, path length $1 \mathrm{~cm}$, max. capacity $=1.5 \mathrm{ml}$ ) were used throughout the study. [Hc] was calculated using the extinction coefficient given by Nickerson \& van Holde (1971) and assuming $\mathrm{M}_{\mathrm{r}}=75 \mathrm{kDa}$ for krill subunits.

To compare the $\mathrm{O}_{2}$-binding properties of $\mathrm{Hc}$ from krill kept under different environmental conditions, pooled haemolymph samples (each $100 \mu \mathrm{l}$ ) were dialysed against a stock crustacean saline solution (buffered at $\mathrm{pH}=7.80$ using Tris) using the micro- method of Horowitz \& Barnes (1983). Oxygen-binding curves for dialysed haemolymph samples were constructed using a spectrophotometric technique (Benesch et al. 1965). Dialysed haemolymph samples were equilibrated against a number of different gas mixtures, produced by precision gas-mixing pumps (Wostoff) and changes in absorbance (at $\lambda=335 \mathrm{~nm}$ ) accompanying step-wise oxygenation of deoxygenated samples were recorded. The half-saturation values $\left(\mathrm{P}_{50}\right)$ were calculated using the Hill equation.

\section{RESULTS}

\section{Physico-chemical characteristics}

The physico-chemical characteristics of the water body where krill were both collected and caged, together with the total chlorophyll concentration, are presented in Fig. 1. There was little significant difference in these characteristics between each of the sampling times, and consequently only data for 3 August are presented. Water temperature was relatively stable between water depths 105 to $40 \mathrm{~m}$ at 6.4 to $7.8^{\circ} \mathrm{C}$ (Fig. 1A). However, thereafter there was an increase in temperature with decreasing depth, with the krill caught at 10 to $20 \mathrm{~m}$ depth being exposed to temperatures of $\sim 15$ to $19^{\circ} \mathrm{C}$, and the surface waters being characterised by temperatures $>20^{\circ} \mathrm{C}$. Like temperature, salinity was relatively constant (34 PSU) over the depth range between 105 and $50 \mathrm{~m}$, although as the water became shallower, salinity decreased to 24.5 PSU at $2 \mathrm{~m}$ depth and 15.9 PSU at $1 \mathrm{~m}$ depth (Fig. 1B). Oxygen too was relatively stable between 105 and $30 \mathrm{~m}\left(\mathrm{PO}_{2}=11\right.$ to $\left.13 \mathrm{kPa}\right)$, although it increased with decreasing depth until the surface waters were reached, where $\mathrm{O}_{2}$ saturation was $>20 \mathrm{kPa}$ (Fig. 1C). Chlorophyll concentration was greatest in surface waters $\left(7 \mathrm{\mu g} \mathrm{l}^{-1}\right)$ but declined dramatically over the range 0 to $30 \mathrm{~m}$ depth (range 20 to $30 \mathrm{~m}=0.2$ to $0.4 \mu \mathrm{g}$ $\mathrm{l}^{-1}$ ) (Fig. 1D). The extremes of temperature, salinity and $\mathrm{O}_{2}$ which the krill experience in nature were used in laboratory experiments, where the effect of altering these parameters on krill [Hc] was estimated.

\section{[Hc] from krill in situ}

The $[\mathrm{Hc}]$ from individual krill collected from different depths (10 to 11 August 1999) are presented in Fig. 2. During the day, no adult krill were found at 10 to 20 or 20 to $30 \mathrm{~m}$ depth. Trawling at 10 to 20 and 20 to $30 \mathrm{~m}$ depth during the night resulted in the capture of krill, but they were considerably fewer (24 to 46 trawl $^{-1}$ ) than those collected from deep water during 
the day ( $>100)$. The $[\mathrm{Hc}]$ of individuals caught in the shallow waters $(10$ to $20 \mathrm{~m}$ depth, $[\mathrm{Hc}]=0.89 \pm$ $0.06 \mathrm{mmol} \mathrm{l}^{-1} ; 20$ to $30 \mathrm{~m}$ depth, $[\mathrm{Hc}]=0.72 \pm$ $0.19 \mathrm{mmol} \mathrm{l}^{-1}$ ) were significantly different from comparable values for individuals trawled at 95 to $110 \mathrm{~m}$ at night (Student's $t$-test, $t=13.91, \mathrm{df}=30$ and $t=6.11$, $\mathrm{df}=53$, respectively, $\mathrm{p}<0.001$ in each case). There was no significant difference in $[\mathrm{Hc}]$ from individuals trawled at 95 to $110 \mathrm{~m}$ during the day compared with those from the same depth trawled during the night (within $36 \mathrm{~h}$ of each other) (Student's $t$-test, $t=-0.93$, $\mathrm{df}=55, \mathrm{p}=0.36$ ).

On 4 separate occasions (during the day), many individuals (107 to 200) were collected from each trawling at 95 to $110 \mathrm{~m}$. There was no significant difference in $[\mathrm{Hc}]$ from individuals collected within this depth range (1-way ANOVA, $F_{3,118}=0.40, \mathrm{p}=0.76,0.57 \pm$ $0.17 \mathrm{mmol} \mathrm{l}^{-1}$ ) despite collection on different dates. In conclusion, krill near the top of the water column had a greater $[\mathrm{Hc}]$ than krill in the deepest water.

The effect on individual $[\mathrm{Hc}]$ and individual survival after caging at different depths for 17 to $18 \mathrm{~h}$ is presented in Table 1. There was a significant correlation between $[\mathrm{Hc}]$ and water depth $\left(\mathrm{r}^{2}=52.6 \%, \mathrm{n}=108\right.$, $\mathrm{p}<0.001)$. Generally $[\mathrm{Hc}]$ increased with decreasing depth, increasing from $0.38 \mathrm{mmol} \mathrm{l}^{-1}$ at $100 \mathrm{~m}$ to $0.74 \mathrm{mmol} \mathrm{l}^{-1}$ at $38 \mathrm{~m}$. Krill caged at a depth of 95 to $105 \mathrm{~m}$ had $[\mathrm{Hc}]$ about $2 / 3$ that of freshly trawled individuals, and this difference was significant (Student's $t$-test, $t=2.17, \mathrm{df}=49, \mathrm{p}=0.035$ ). However, there was no significant difference in [Hc] from krill caught at 20 to $30 \mathrm{~m}$ at night and individuals caged at a depth of $38 \mathrm{~m}$ (Student's $t$-test, $t=0.11, \mathrm{df}=36, \mathrm{p}=0.91$ ). Survival was lower in the deeper cages.

In a second experiment, there were no survivors amongst caged krill $0.5,1$ or $2 \mathrm{~h}$ after deployment at 5 to $10 \mathrm{~m}$. Consequently, we were unable to collect haemolymph samples for the individuals caged at this depth.

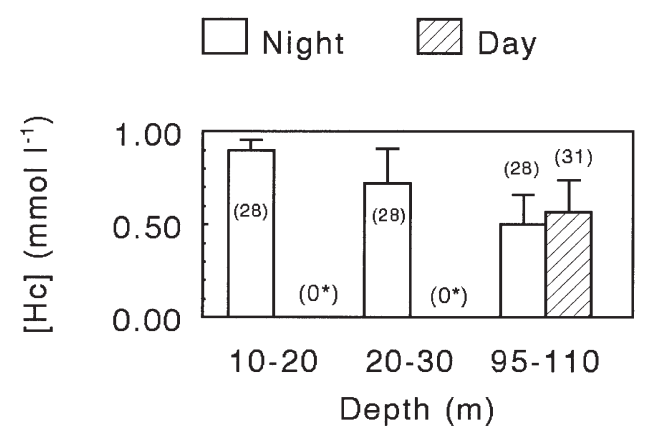

Fig. 2. The $[\mathrm{Hc}]$ from individual krill trawled at different depths during the day and night. Values are expressed as means $\pm 1 \mathrm{SD}$. Figures in parentheses are the number of individuals examined. * number of individuals present in trawl

\section{Effect of hypoxia and salinity in the laboratory}

Exposure of fed krill to hypoxia over a $4 \mathrm{~d}$ period had no significant effect on [Hc] (2-way ANOVA, $F_{1,63}=$ $0.13, \mathrm{p}=0.72$ ) which was $0.50 \pm 0.06 \mathrm{mmol} \mathrm{l}^{-1}$ (Fig. 3). However, there was a significant effect of time $\left(F_{3,63}=\right.$ 16.17, $\mathrm{p}<0.01$ ).

Neither was there a significant effect of salinity (28 to $35 \mathrm{PSU}$ ) on [Hc] (2-way ANOVA, $F_{1,50}=0.04$, $\mathrm{p}=0.84,0.46 \pm 0.04 \mathrm{mmol} \mathrm{l}^{-1}$; Fig. 4), although, again, there was an effect of time $\left(F_{3,50}=3.26, p=0.03\right)$. Exposure of krill to even lower salinities, namely 21,14 and $7 \mathrm{PSU}$, resulted in $100 \%$ mortality over the test period, and so it was not possible to examine changes in $[\mathrm{Hc}]$ as a result of exposure to more 'extreme' salinities.

\section{Effect of temperature and starvation in the laboratory}

Presented in Fig. 5 are data on the effect of keeping krill at 2 different environmental temperatures for

Table 1. The [Hc] of individual krill caged at different depths in the Gullmarsfjord from 10 to 11 August 1999, together with details of cage deployment and retrieval. ${ }^{*} 15$ individuals unaccounted for. ${ }^{* *}$ No measurements obtained as no individuals were in intermoult

\begin{tabular}{|lcccc|}
\hline $\begin{array}{c}\text { Measured depth } \\
(\mathrm{m})\end{array}$ & $\begin{array}{c}{[\mathrm{Hc}] \mathrm{mmol} \mathrm{l}{ }^{-1}} \\
\text { mean } \pm 1 \mathrm{SD}\end{array}$ & $\begin{array}{c}\text { Number of individuals } \\
\text { examined }\end{array}$ & $\begin{array}{c}\text { Survival (number of } \\
\text { individuals alive/dead) }\end{array}$ & Latitude, Longitude \\
\hline 38 & $0.84 \pm 0.24$ & 14 & $19 / 7$ & $58^{\circ} 19^{\prime} 07 \mathrm{~N}^{\prime} 11^{\circ} 32^{\prime} 88 \mathrm{E}$ \\
42 & $0.79 \pm 0.19$ & 8 & $22 / 8$ & $58^{\circ} 19^{\prime} 01 \mathrm{~N}^{\prime} 11^{\circ} 32^{\prime} 72 \mathrm{E}$ \\
48 & $0.79 \pm 0.21$ & 21 & $24 / 6$ & $58^{\circ} 19^{\prime} 05 \mathrm{~N}^{\prime} 11^{\circ} 32^{\prime} 85 \mathrm{E}$ \\
60 & $0.78 \pm 0.50$ & 14 & $19 / 11$ & $58^{\circ} 19^{\prime} 01 \mathrm{~N}^{\prime} 11^{\circ} 32^{\prime} 72 \mathrm{E}$ \\
67 & $0.79 \pm 0.30$ & 12 & $20 / 10$ & $58^{\circ} 19^{\prime} 07 \mathrm{~N}^{\prime} 11^{\circ} 32^{\prime} 88 \mathrm{E}$ \\
72 & $0.60 \pm 0.23$ & 19 & $17 / 4$ & $58^{\circ} 19^{\prime} 05 \mathrm{~N}^{\prime} 11^{\circ} 32^{\prime} 85 \mathrm{E}$ \\
95 & $0.53 \pm 0.12$ & 9 & $11 / 19$ & $58^{\circ} 19^{\prime} 05 \mathrm{~N}^{\prime} 11^{\circ} 32^{\prime} 85 \mathrm{E}$ \\
100 & $0.48 \pm 0.13$ & 0 & $4 / 11^{*}$ & $58^{\circ} 19^{\prime} 01 \mathrm{~N}^{*} 11^{\circ} 32^{\prime} 72 \mathrm{E}$ \\
105 & $*$ & $58^{\circ} 19^{\prime} 07 \mathrm{~N}^{\prime} 11^{\circ} 32^{\prime} 88 \mathrm{E}$ \\
\hline
\end{tabular}




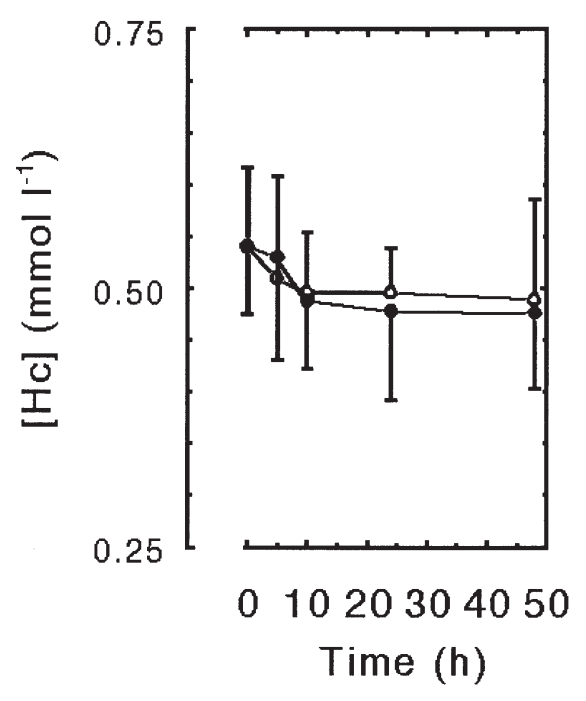

Fig. 3. Effect of exposure to hypoxia on $[\mathrm{Hc}]$ from fed krill. $(\circ)$ control (normoxia) and $(\bullet)$ experimental (hypoxia). Values are expressed as means \pm 1 SD. $n=8$ in each case

$10 \mathrm{~h}$, both with and without food. There was a significant interactive effect of temperature and starvation on [Hc] $\left(2\right.$-way ANOVA, $\left.F_{1,64}=56.73, \mathrm{p}<0.001\right)$. Fed individuals kept at $7^{\circ} \mathrm{C}$ had a reduced [Hc] compared with fed individuals kept at $14^{\circ} \mathrm{C}$ (open bars in Fig. 5). However, starved individuals at $7^{\circ} \mathrm{C}$ possessed a greater [Hc] than starved individuals kept at $14^{\circ} \mathrm{C}$ (hatched bars in Fig. 5). Furthermore, fed individuals invariably had greater $[\mathrm{Hc}]$ than starved individuals when compared at the same environmental temperature, but the difference was most pronounced at $\mathrm{T}=14^{\circ} \mathrm{C}$. In summary, starvation resulted in a decrease in $[\mathrm{Hc}]$ which was more pronounced at the higher temperature.

Table 2. Values for half-saturation $\left(\mathrm{P}_{50}\right)$ of $\mathrm{Hc}$ from krill taken straight from the field and krill kept under the different environmental conditions in the laboratory. Values given are means $\pm 1 \mathrm{SD}$ with the number of determinations given in parentheses

\begin{tabular}{|lll|}
\hline & & $\mathrm{P}_{50}(\mathrm{kPa})$ \\
\hline Field-collected & & \\
& & \\
& 20 to $30 \mathrm{~m}$ depth (night) & $6.28 \pm 0.17(5)$ \\
& 90 to $100 \mathrm{~m}$ depth (night) & $6.22 \pm 0.14(5)$ \\
& 90 to $100 \mathrm{~m}$ depth (day) & $6.28 \pm 0.18(5)$ \\
Environmental factor & & \\
Hypoxia (50 h exposure) & $\mathrm{PO}_{2}=17.9 \mathrm{kPa}$ & $6.16 \pm 0.19(4)$ \\
& $\mathrm{PO}_{2}=8.1 \mathrm{kPa}$ & $6.12 \pm 0.22(4)$ \\
Salinity (50 h exposure) & $35 \mathrm{PSU}$ & $6.31 \pm 0.18(4)$ \\
& $27 \mathrm{PSU}$ & $6.19 \pm 0.23(3)$ \\
Temperature and feeding & $\mathrm{T}=7^{\circ} \mathrm{C}$ fed & $6.27 \pm 0.18(5)$ \\
regime (12 h exposure) & $\mathrm{T}=7^{\circ} \mathrm{C}$ starved & $6.19 \pm 0.17(5)$ \\
& $\mathrm{T}=14^{\circ} \mathrm{C}$ fed & $6.26 \pm 0.17(5)$ \\
& $\mathrm{T}=14^{\circ} \mathrm{C}$ starved & \\
\hline
\end{tabular}

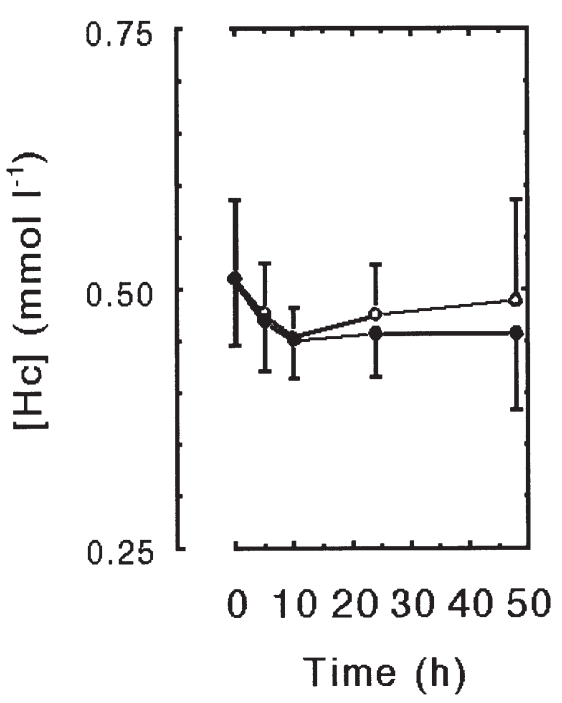

Fig. 4. Effect of exposure to hyposaline conditions on [Hc] from fed krill. ( $(\circ) 35$ PSU and (•) 28 PSU. Values are expressed as means \pm 1 SD. $n=6$ to 8 in each case

While there was an increase in [Hc] with increasing temperature in fed individuals, this was reversed in starved individuals where an increase in temperature resulted in a small decrease in $[\mathrm{Hc}]$.

\section{Effect of moulting on [Hc]}

In Fig. 6, the relationship between $[\mathrm{Hc}]$ and moult stage in Meganyctiphanes norvegicus is presented. There was an increase in [Hc] from $0.69 \pm 0.11 \mathrm{mmol} \mathrm{l}^{-1}$ in Stage A individuals to $1.29 \pm 0.37 \mathrm{mmol} \mathrm{l}^{-1}$ in Stage D1 individuals. Thereafter, $[\mathrm{Hc}]$ decreased to $0.81 \pm$ $0.13 \mathrm{mmol} \mathrm{l}^{-1}$. There were no significant differences between males and females at each of the moult classes examined (Student's $t$-test, $\mathrm{p}>0.05$ in each case).

\section{Effect of environmental variables on $\mathrm{HcO}_{2}$ affinity}

Presented in Table 2 are values for half-saturation $\left(\mathrm{P}_{50}\right)$ of Hc from krill collected at different water depths from the field and krill kept under the different laboratory conditions. There was no significant difference in $\mathrm{P}_{50}$ between $\mathrm{Hc}$ of individuals collected from 20 to $30 \mathrm{~m}$ and those collected from $>90 \mathrm{~m}$ depth (Student's $t$-test, $t=$ 0.13, df $=7, p=0.90$ ). Similarly, there 


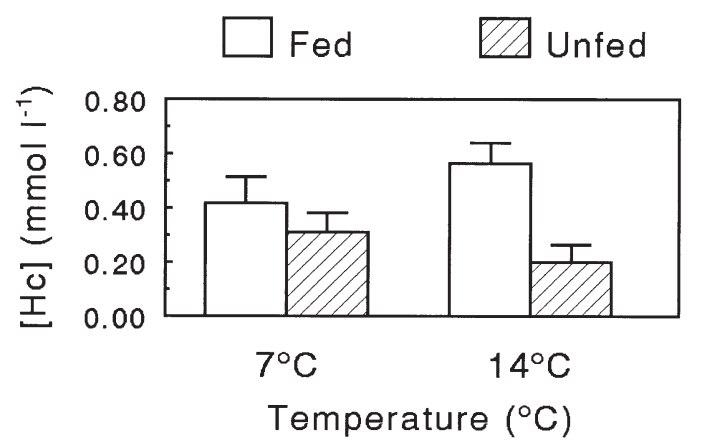

Fig. 5. Effect of temperature and starvation on krill [Hc] after $10 \mathrm{~h}$. Values are expressed as means $\pm 1 \mathrm{SD}$. $\mathrm{n}=15$ to 18 in each case

was no significant difference in $\mathrm{P}_{50}$ between individuals caught $>90 \mathrm{~m}$ depth during the day and those caught during the night (Student's $t$-test, $t=1.52$, $\mathrm{df}=4, \mathrm{p}>0.20)$.

For individuals used in laboratory experiments, there was no significant differences in $\mathrm{P}_{50}$ as a result of temperature, $\mathrm{PO}_{2}$, salinity or feeding status (Student's $t$-test, p $>0.05$ in each case).

\section{DISCUSSION}

\section{Patterns}

Meganyctiphanes norvegica possessed an extremely variable [Hc] $\left(0.39\right.$ to $\left.0.89 \mathrm{mmol} \mathrm{l}^{-1}\right)$. This range was not dissimilar to that given by Truchot (1992), of 0.3 to $1.0 \mathrm{mmol} \mathrm{l}^{-1}$, which he presented as typical for arthropods generally. Clearly, intraspecific variation in [Hc] can be as great as interspecific variation. Some of the variation encountered is associated with the depth at which $M$. norvegica occur in the water column during their DVM. Increasing depth was associated with decreasing $[\mathrm{Hc}]$. This pattern was the same for trawled (at night) and for caged krill.

One of the most exciting findings presented here is that $[\mathrm{Hc}]$ changes over a very short time scale $(\leq 10 \mathrm{~h})$. Most previous studies have examined the effect of intrinsic and environmental factors on [Hc] only over periods of days or even weeks (e.g. Wieser 1965, Uglow 1969, Djangmah 1970, Dall 1974, Boone \& Schoffeniels 1979, Rutledge 1981, Senkbiel \& Wriston 1981, Hagerman 1983, 1986, Mason et al. 1983, Hagerman \& Oksama 1985, Hagerman \& Uglow 1985, Baden et al. 1990, DeFur et al. 1990). This said, a recent study on the effect of hypoxia on [Hc] in the Norway lobster Nephrops norvegicus showed that changes could be induced in $<24 \mathrm{~h}$ (Spicer \& Baden 2001). While there were dramatic changes noted in $[\mathrm{Hc}]$, by contrast none

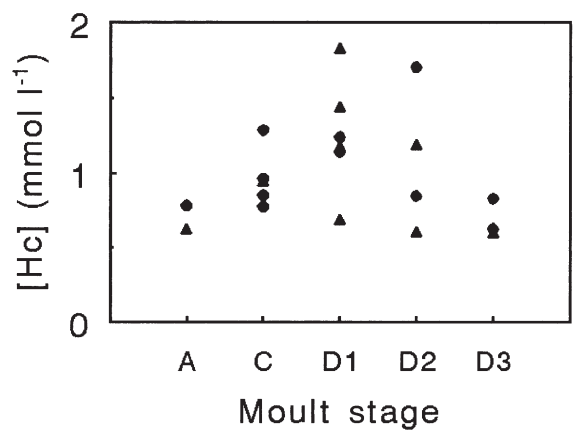

Fig. 6. Changes in [Hc] related to different stages of the moult cycle in Meganyctiphanes norvegicus. Each point represents a single determination. $(\bullet)$ Males and $(\boldsymbol{\bullet})$ females

of the factors examined affected $\mathrm{HcO}_{2}$ affinity. Haemocyanin from Meganyctiphanes norvegica had a very low $\mathrm{O}_{2}$ affinity $\left(\mathrm{P}_{50}=6.26 \mathrm{kPa}\right.$ [47 torr], $\mathrm{pH}=8.00, \mathrm{~T}=$ $7^{\circ} \mathrm{C}$ ), as did the only other krill species for which we have data, Euphausia superba (Bridges et al. 1983: $\mathrm{P}_{50}=3.35 \mathrm{kPa}$ [25 torr], $\mathrm{pH}=8.23, \mathrm{~T}=-1.5^{\circ} \mathrm{C}$ ). Without knowledge of arterial and venous $\mathrm{PO}_{2} \mathrm{~S}$, however, it is unhelpful and unwise to speculate on the significance of $\mathrm{O}_{2}$-binding data for krill respiratory function.

\section{Mechanisms}

Hypoxia and salinity

It is not unreasonable to suggest that the correlation between [Hc] and depth may be explained by differences in key environmental factors that also vary with depth, namely $\mathrm{PO}_{2}$, salinity and temperature. However, there was no increase in $[\mathrm{Hc}]$ either as a result of exposure to hypoxia or hyposaline conditions: nor were there changes in intrinsic $\mathrm{HcO}_{2}$ binding. This was contrary to what has been found for many other crustacean species (see 'Introduction' for references).

Temperature and the influence of starvation

Data on the effect of temperature on [Hc] and intrinsic $\mathrm{HcO}_{2}$ affinity are rare. Truchot (1975) found that keeping shore crabs Carcinus maenas at 15 and $30^{\circ} \mathrm{C}$ for 2 to $3 \mathrm{~d}$ resulted in different $\mathrm{HcO}_{2}$ affinities. These differences were only partially removed by dialysis. Also, keeping crayfish Pacifastacus leniusculus at 10 and $25^{\circ} \mathrm{C}$ for 1 mo showed that with an increase in temperature there was an increase in $\mathrm{HcO}_{2}$ affinity and a decrease in cooperativity (Rutledge 1981). Rutledge (1981) also found that [Hc] increased with a decrease in environmental temperature. In agreement with Rut- 
ledge (1981), we found that an increase in experimental temperature did result in a small but significant decrease in $[\mathrm{Hc}]$ in starved Meganyctiphanes norvegica, although there was no alteration in $\mathrm{HcO}_{2}$ affinity. However, for fed $M$. norvegica the opposite was true. An increase in temperature resulted in an increase in $[\mathrm{Hc}]$, although there was still no change in affinity. Clearly the feeding status of $M$. norvegica influences the effect of temperature on the induction and/or catabolism of Hc. It could be that an increase in temperature results in an increase in krill [Hc], but under conditions of starvation the rate of use of Hc as an energy source increases, thereby off-setting any temperature-related increase in [Hc] (see next subsection). Thus, while it is plausible that, to some extent, the relationship between $[\mathrm{Hc}]$ and depth we observed could be explained by plastic, temperature-induced changes in $[\mathrm{Hc}]$, the magnitude and direction of $[\mathrm{Hc}]$ changes in the laboratory should make us cautious about drawing such a conclusion.

\section{Starvation}

The dramatic effect of starvation on crustacean [Hc] was first noted in the 1920s (Redfield et al. 1926). Since then, more detailed studies have been carried out. Djangmah (1970) observed that [Hc] decreased from 1.0 to $0.3 \mathrm{mmol} \mathrm{l}^{-1}$ in the shrimp Crangon crangon (as C. vulgaris) after $23 \mathrm{~d}$ of starvation. Furthermore, haemolymph $\left[\mathrm{Cu}^{2+}\right]$ which after $37 \mathrm{~d}$ of starvation were about $1 /{ }_{7}$ of control (fed) values, had increased to about $1 / 2$ of that control value after being re-fed for $10 \mathrm{~d}$. Hagerman (1983) also found a decrease in [Hc] with starvation for juvenile lobsters Homarus gammarus, with the concentration dropping from 0.5 to $0.2 \mathrm{mmol} \mathrm{l}^{-1}$ after $22 \mathrm{wk}\left(\mathrm{T}=3^{\circ} \mathrm{C}, \mathrm{S}=28 \mathrm{PSU}\right)$. However, much of the reduction seemed to have taken place in the first 2 to $6 \mathrm{wk}$. This followed roughly the pattern described for adult lobsters Homarus americanus (Stewart et al. 1967). As in all previous investigations, starvation had a dramatic effect on [Hc] (although not over such a short timescale). Furthermore, starvation-related decreases in $[\mathrm{Hc}]$ were exacerbated by increasing experimental temperature-so much so that it is suggested that while an increase in temperature may result in a slight increase in [Hc] from well-fed krill, under conditions of starvation the rate of use of Hc as an energy source increased, off-setting any temperature-related increase in $[\mathrm{Hc}]$. This led to the seemingly paradoxical situation where exposure to high temperature resulted in a modest increase in [Hc] in fed individuals but a decrease in $[\mathrm{Hc}]$ in starved individuals. In this connection, it is interesting that in the hypoxia and salinity experiments described above, there was an initial decrease in [Hc] with time, in both control and experimental treatments, although this seemed to level off in the longer term. Even though krill were fed in many treatments, it is possible that at the stocking density used they may have significantly reduced the food available. If so, this lends support to the hypothesis of a starvation-related decrease in $[\mathrm{Hc}]$.

\section{Moulting}

Although we used only intermoult individuals, we investigated the effect of the moult cycle on [Hc] to see if this could be an important source of variation in the field. As with shrimps (Djangman 1979) and lobsters (Hagerman 1983), there was an increase in [Hc] with increasing moult stage, with the lowest values occurring during the moult. The magnitude of these differences in krill [Hc] means that future investigations must be very careful in either standardising for or taking account of moult stage.

In conclusion, the feeding status of Meganyctiphanes norvegica has a greater impact on $[\mathrm{Hc}]$ than any of the other factors examined, although high temperatures did exacerbate this impact. Consequently, based on our laboratory studies, the best way to explain the pattern of decreasing [Hc] with increasing depth is probably by implicating changes in the feeding regime of krill at different stages in their DVM.

\section{DVM, feeding and $[\mathrm{Hc}]$}

Generally, Meganyctiphanes norvegica fed on detritus and phytoplankton in the upper layers during the day, but had a more mixed diet, including copepods, in deep water during the night (Sameoto 1980, Onsrud \& Kaartvedt 1998). In Kattegat populations, however, little feeding took place in deeper waters during the day (Lass et al. 2001). We found that individuals trawled from deeper waters, irrespective of time of day, had relatively low [Hc] compared with individuals caught in shallow waters at night. This suggests that the principal food was concentrated in the surface layers and that more food was consumed in surface waters compared with deep waters. Consequently, the evening ascent into surface layers would increase food availability, but the morning descent would involve krill migrating into an environment where energy acquisition could be a problem. Thus, we advance the hypothesis that when $M$. norvegica migrates into deep water during the day, for whatever reason (predator avoidance or reduced prey abundance, or reduced ability to locate and capture prey), they cannot secure enough energy to meet routine 
metabolic demands and so break down Hc to use it as an energy source.

The use of Hc as an energy source during starvation has been suggested before (Weiser 1965, Uglow 1969, Djangmah 1970, Hagerman 1983). Furthermore, the relatively high metabolic rates recorded for Meganyctiphanes norvegica (van den Thillart et al. 1999, Strömberg \& Spicer 2001) collected from the Gullmarsfjord, together with suggestions that this species can barely meet its metabolic demands when feeding on particular types of food (McClatchie 1985), adds weight to the idea of these individuals needing to break down Hc molecules as an energy source when they leave the energy-rich surface waters around dawn. Given the high $Q_{10}$ of $M$. norvegica respiration, the lower temperature of the bottom waters in the Gullmarsfjord means that energy demand of individual animals will fall dramatically (Strömberg \& Spicer 2001) when they begin their downward migration. Such a reduction in temperature should off-set, to some extent, the starvation-related decrease in $[\mathrm{Hc}]$, given that this decrease is so sensitive to temperature.

The rapid decrease in $[\mathrm{Hc}]$ observed here during starvation is of greater magnitude than recorded for other crustaceans. Although it is impossible to be definitive without data for pre- and post-branchial $\mathrm{O}_{2}$ tensions in Meganyctiphanes norvegica, it is difficult to see how $\mathrm{O}_{2}$ transport will not be compromised by large changes in [Hc] over such a short timescale. Thus, when krill migrate into deep waters during their DVM, a trade-off may take place between the use of $\mathrm{Hc}$ as a respiratory pigment and $\mathrm{Hc}$ as a source of nutrition. The energetic costs and benefits of such a trade-off, which require data on Hc turnover rates and energy content, remain to be elucidated.

Acknowledgements. We thank M. St Johns for supplying the diatoms used to feed the krill and P. Tiselius for help with their culture, the crew of the RV 'Arne Tiselius' and G. Schultz for their assistance in collecting animal material. We also thank M. Attrill, N. Holmes and M. B. Jones for criticising early drafts, and 3 referees for their valuable criticism. This study was carried out while J.I.S. was in receipt of an EU/TMR grant and J.O.S. had support from the Royal Swedish Academy of Science via Kristineberg Marine Research Station.

\section{LITERATURE CITED}

Alonzo SH, Mangel M (2001) Survival strategies and growth of krill: avoiding predators in space and time. Mar Ecol Prog Ser 209:203-217

Baden SP, Pihl L, Rosenberg R (1990) Effects of oxygen depletion on the ecology, blood physiology and fishery of the Norway lobster Nephrops norvegicus. Mar Ecol Prog Ser 67:141-155

Banse K (1964) On the vertical distribution of zooplankton in the sea. Prog Oceanogr 2:53-125
Benesch R, MacDuff G, Benesch RE (1965) Determination of oxygen equilibrium with a versatile new tonometer. Anal Biochem 11:81-87

Boone WR, Schoffeniels E (1979) Hemocyanin synthesis during hypo-osmotic stress in the shore crab Carcinus maenas (L.). Comp Biochem Physiol 63B:207-214

Bridges C, Savel A, Stöcker W, Markl J, Linzen B (1983) Structure and function of krill (Euphausia superba) haemocyanin-adaptation to life at low temperature. Life Chem Rep Suppl 1:353-356

Bridges CR (2001) Modulation of haemocyanin oxygen affinity: properties and physiological implications in a changing world. J Exp Biol 204:1021-1032

Buchholz F (1982) Drach's molt staging system adapted for euphausiids. Mar Biol 66:301-305

Buchholz F, Buchholz C, Reppin J, Fischer J (1995) Diel vertical migrations of Meganyctiphanes norvegica in the Kattegat: comparison of net catches and measurements with Acoustic Doppler Current Profilers. Helgol Wiss Meeresunters 49:849-866

Dall W (1974) Indices of nutritional state in the western rock lobster, Panulirus longipes (Milne Edwards). I. Blood and tissue constituents and water content. J Exp Mar Biol Ecol 16:167-180

DeFur PL, Mangum CP, Reese JE (1990) Respiratory responses of the blue crab Callinectes sapidus to long-term hypoxia. Biol Bull (Woods Hole) 178:46-54

Djangmah JS (1970) The effects of feeding and starvation on copper in the blood and hepatopancreas, and on blood proteins of Crangon vulgaris (Fabricius). Comp Biochem Physiol 32:709-731

Hagerman L (1983) Haemocyanin concentration in juvenile lobsters (Homarus gammarus) in relation to moulting cycle and feeding conditions. Mar Biol 77:11-17

Hagerman L (1986) Haemocyanin concentration in the shrimp Crangon crangon (L.) after exposure to moderate hypoxia. Comp Biochem Physiol 85A:721-724

Hagerman L, Oksama M (1985) Haemocyanin concentration, carrying capacity and haemolymph $\mathrm{pH}$ under hypoxia in Mesidothea entomon (L.) (Isopoda, Crustacea). Ophelia $24: 47-52$

Hagerman L, Uglow RF (1985) Effects of hypoxia on the respiratory and circulatory regulation of Nephrops norvegicus. Mar Biol 87:273-278

Horowitz PM, Barnes LD (1983) A simple, inexpensive and precise microcell for the exchange dialysis of small samples. Anal Biochem 128:478-480

Lampert W (1989) The adaptive significance of diel vertical migration of zooplankton. Funct Ecol 3:21-27

Lass S, Tarling GA, Virtue $\mathrm{P}$, Matthews JBL, Mayzaud $\mathrm{P}_{1}$ Buchholz F (2001) On the food of northern krill Meganyctiphanes norvegica in relation to its vertical distribution. Mar Ecol Prog Ser 214:177-200

Liljebladh B, Thomasson MA (2001) Krill behaviour as recorded by acoustic doppler current profilers in the Gullmarsfjord. J Mar Syst 27:301-313

Mangum CP (1983) Oxygen transport in the blood. In: The biology of Crustacea, Vol 5. Internal anatomy and physiological regulation. Academic Press, New York, p 373-429

Mangum CP (1990) Inducible $\mathrm{O}_{2}$ carriers in crustaceans. Comp Physiol 6:92-103

Mangum CP (1994) Subunit composition of hemocyanins of Callinectes sapidus: Phenotypes from naturally hypoxic waters and isolated oligomers. Comp Biochem Physiol 108B:537-541

Mangum CP (1997) Invertebrate blood oxygen carriers. In: Dantzler WH (ed) Handbook of physiology, Section 13. 
Comparative physiology, Vol 2. Oxford Univ Press, New York, p 1097-1135

Mason RP, Mangum CP, Godette G (1983) The influence of inorganic ions and acclimation salinity on hemocyaninoxygen binding in the blue crab Callinectes sapidus. Biol Bull (Woods Hole) 164:104-123

Mauchline J (1980) The biology of mysids and euphasiids. Adv Mar Biol 18:1-681

Mauchline J, Fisher LR (1969) The biology of euphausiids. Adv Mar Biol 7:1-454

Mayzaud P (1973) Respiration and nitrogen excretion of zooplankton. II. Studies of the metabolic characteristics of starved animals. Mar Biol 21:19-28

McClatchie S (1985) Feeding behaviour in Meganyctiphanes norvegica (M. Sars) (Crustacea: Euphausiacea). J Exp Mar Biol Ecol 86:271-284

Nickerson KW, van Holde KE (1971) A comparison of molluscan and arthropod haemocyanin. I. Circular dichromism and absorption spectra. Comp Biochem Physiol 39B: 855-872

Onsrud MSR, Kaartvedt S (1998) Diel vertical migration of the krill Meganyctiphanes norvegica in relation to physical environment, food and predators. Mar Ecol Prog Ser 171: 209-219

Redfield AC, Coolidge T, Hurd AL (1926) The transport of oxygen and carbon dioxide by some blood containing hemocyanin. J Biol Chem 69:475-509

Rutledge PS (1981) Effect of temperature acclimation on crayfish hemocyanin binding. Am J Physiol 240:R93-R98

Sameoto DD (1980) Relationships between stomach contents and vertical migration in Meganyctiphanes norvegica, Thysanoessa raschii and T. inermis (Crustacea: Euphausidacea). J Plankton Res 2:129-143

Schlieper C (1972) Research methods in marine biology. Sidgwick and Jackson, London

Senkbiel EG, Wriston JC Jr (1981) Hemocyanin synthesis in the American lobster Homarus americanus. Comp Biochem Physiol 68B:163-171

Simmard Y, Lacroix G, Legendre L (1986) Diel vertical migrations and nocturnal feeding of a dense coastal krill scattering layer (Thysanoessa raschi and Meganyctiphanes norvegica) in stratified surface waters. Mar Biol 91:93-105

Editorial responsibility: Otto Kinne (Editor),

Oldendorf/Luhe, Germany
Spicer JI, Baden SP (2000) Natural variation in the concentrations of haemocyanin from three decapod crustaceans, Nephrops norvegicus, Liocarcinus depurator and Hyas aranaeus. Mar Biol 136:55-61

Spicer JI, Baden SP (2001) Environmental hypoxia and haemocyanin between-individual variability in Norway lobsters Nephrops norvegicus (L.) Mar Biol 139:727-734

Spicer JI, Thomasson MA, Strömberg JO (1999) Possessing a poor anaerobic capacity does not prevent the diel vertical migration of Nordic krill Meganyctiphanes norvegica into hypoxic waters. Mar Ecol Prog Ser 185:181-187

Stewart JE, Cornick JW, Foley DM, Bishop CM (1967) Muscle weight relationship to serum proteins, hemocytes and hepatopancreas in the lobster Homarus americanus. J Fish Res Board Can 24:2339-2354

Strömberg JO, Spicer JI (2001) Cold comfort for krill? Respiratory consequences of diel vertical migration of Meganyctiphanes norvegica into deep hypoxic waters. Ophelia 53:213-217

Tarling GA, Matthews JBL, Sabarowski R, Buchholz F (1998) Vertical migratory behaviour of the euphausiid Meganyctiphanes norvegica and its dispersion in the Kattegat Channel. Hydrobiologia 375/376:331-341

Tarling GA, Matthews JBL, Burrows M, Saborowski R, Buchholz F, Bedo A, Mayzuad P (2000) An optimisation model of the diel vertical migration of 'Northern krill' (Meganyctiphanes norvegica) in the Clyde Sea and Kattegat. Can J Fish Aquat Sci (Suppl 3) 57:38-50

Truchot JP (1975) Factors controlling the in vitro and in vivo oxygen affinity of the hemocyanin of the crab, Carcinus maenas (L.). Respir Physiol 24:173-189

Truchot JP (1992) Respiratory function of arthropod hemocyanins. Adv Comp Environ Physiol 13:377-410

Uglow RF (1969) Haemolymph protein concentrations in portunid crabs. II. The effects of imposed fasting on Carcinus maenas. Comp Biochem Physiol 31:959-967

van den Thillart G, George RY, Strömberg JO (1999) Hypoxia sensitivity and respiration of the euphausiid crustacean Meganyctiphanes norvegica from Gullmarn Fjord, Sweden. Sarsia 85:105-109

Wieser W (1965) Electrophoretic studies on blood proteins in an ecological series of isopod and amphipod species. J Mar Biol Assoc UK 45:507-523

Submitted: August 8, 2001; Accepted: February 15, 2002

Proofs received from author(s): July 12, 2002 